\title{
HUBUNGAN LAMA TINGGAL DENGAN TINGKAT DEPRESI PADA LANJUT USIA DI PANTI SOSIAL TRESNA WERDHA 'AGAPE' TONDANO
}

\author{
${ }^{1}$ Inri F. Moniung \\ ${ }^{2}$ Anita E. Dundu \\ ${ }^{2}$ Herdy Munayang
}
${ }^{1}$ Kandidat Skripsi Fakultas Kedokteran Universitas Sam Ratulangi Manado
${ }^{2}$ Bagian Psikiatri Fakultas Kedokteran Universitas Sam Ratulangi Manado E-mail:Imoniung11_054@yahoo.co.id

\begin{abstract}
Depression is a serious problem in the society. According to World Health Organization in 2000, depression is on fourth rank in the world as the disease causing disability and will be raised to second rank of health problem in 2020. Elderly is a hard phase of human life. In this period, the elderly are often confronted with problems such as physical limitations and losing their role in society that could make them more susceptible to get depression. Moreover, elderly who stay at nursing home have the feeling as if they are not worthy anymore, be discarded from their family, and start blaming themselves. This was an analytical study with a cross-sectional research design. Level of depression of fifty elderly people will be rated using the questionnaire of Hamilton Depression Rate Scale. data were statistically analyzed (univariate and bivariate). The results showed that $4.0 \%$ elderly were normal, 34.0\% had mild depression, 56.0\% had moderate depression, $6.0 \%$ had severe depression. There was no relation between length of stay with level of depression among elderly in Panti Sosial Tresna Werdha Agape Tondano.
\end{abstract}

Keywords: depression, elderly, Hamilton depression rate scale.

\begin{abstract}
Abstrak: World Health Organization menyatakan depresi berada pada urutan keempat penyakit di dunia penyebab kecacatan dan pada tahun 2020 akan meningkat menduduki peringkat kedua masalah kesehatan dunia. Masa lanjut usia merupakan tahap kehidupan yang tidak mudah. Pada periode ini lanjut usia dihadapkan dengan berbagai kendala baik kemunduran fisik maupun kehilangan peran sosialnya sehingga menyebabkan lanjut usia cenderung lebih rentan mengalami depresi. Lanjut usia yang tinggal di panti werdha karena terpaksa merasa tidak berharga, menyalahkan diri sendiri, dan merasa diri dibuang oleh keluarga. Penelitian ini bersifat analitik dengan desain potong lintang. Tingkatan depresi pada 50 orang lanjut usia dinilai dengan menggunakan kuesioner Hamilton Depression Rate Scale. Hasil penelitian diolah dengan analisis univariat dan bivariat. Hasil penelitian menunjukkan sebanyak 4,0\% lanjut usia tidak mengalami depresi, 34,0\% lanjut usia dengan depresi ringan, 56,0\% lanjut usia dengan depresi sedang, 6,0\% dengan depresi berat. Tidak terdapat hubungan lama tinggal dan tingkat depresi pada lanjut usia di Panti Sosial Tresna Werdha Agape Tondano.
\end{abstract}

Kata kunci: depresi, lanjut usia, Hamilton depression rate scale

Depresi merupakan masalah kesehatan yang serius di masyarakat. Menurut World Health Organization (WHO) tahun 2000 menyatakan depresi berada pada urutan keempat penyakit di dunia penyebab kecacatan dan pada tahun 2020 depresi akan meningkat dan bisa saja menduduki peringkat kedua dalam masalah kesehatan 
dunia. ${ }^{1}$ Menurut Rice, depresi merupakan gangguan mood berkepanjangan yang mewarnai seluruh proses mental seseorang. Pada umumnya mood yang secara dominan muncul ialah perasaan tidak berdaya dan kehilangan harapan. ${ }^{2}$

Di Amerika, depresi mempengaruhi 19.000.000 orang dewasa dan yang lebih mengkhawatirkan 2,5\% depresi terjadi pada anak-anak dan 8,3\% remaja mengalami depresi. Rata-rata usia rentan mengalami depresi yaitu pada usia kira-kira 40 tahunan. ${ }^{3}$ Di Indonesia pada Juni 2004 sekitar $94 \%$ masyarakat Indonesia mengalami depresi mulai dari tingkat ringan sampai berat. ${ }^{4}$

Depresi ditandai dengan adanya perasaan sedih, murung dan iritabilitas, timbul rasa bersalah, perasaan tidak berharga, kepercayaan diri turun, pesimis dan putus asa. Sampai saat ini belum ada etiologi yang pasti sebagai penyebab depresi. Ada beberapa prediktor penyebab depresi, yaitu mulai dari faktor genetik sampai dengan faktor non genetik. ${ }^{5}$

Lanjut usia dimulai saat seseorang mulai memasuki usia 60 tahun yang mempunyai resiko rentan terhadap berbagai masalah kesehatan.Lansia mengalami perubahan peran dalam keluarga, sosial ekonomi maupun sosial masyarakat yang mengakibatkan kemunduran dalam beradaptasi dengan lingkungan baru dan berinteraksi dengan lingkungan sosialnya. Lansia yang tinggal di panti wredha akan mengalami paparan terhadap lingkungan dan teman baru yang mengharuskan lansia beradaptasi secara positif ataupun negatif. Kegagalan respon adaptif yang ditandai dengan kegagalan dalam berinteraksi, kurang pedulinya keluarga, dan asset maupun tabungan yang tidak memenuhi kebutuhan menyebabkan kekhawatiran serta disentegrasi pada lansia. Kekhawatiran yang berlebih merupakan satu gejala psikologis yang menunjukan adanya kecemasan. Kecemasan yang terjadi di luar kendali dan berlangsung lama serta menganggu aktivitas sehari-hari, maka dapat berkembang menjadi suatu kondisi klinis yang disebut Generalized Anxiety
Disorder dan sangat mempengaruhi kehidupan penderita sehingga terjadi depresi. $^{6}$

Pada orang lanjut usia, gejala-gejala depresi dapat berupa perasaan sedih, tidak bahagia, sering menangis, merasa kesepian, tidur terganggu, pikiran dan gerakan tubuh lamban, cepat lelah dan menurunnya aktivitas. Tidak ada selera makan, berat badan berkurang, daya ingat menurun, sulit memusatkan pikiran dan perhatian, minat berkurang, kesenangan yang biasanya dinikmati menjadi hilang, menyusahkan orang lain, merasa rendah diri, harga diri dan kepercayaan diri berkurang, muncul perasaan bersalah dan tidak berguna, tidak ingin hidup lagi dan bahkan mau bunuh diri. $^{7}$

Berbagai proses yang berhubungan dengan bertambah usia dan penyakit fisik yang dialami akan mempengaruhi integritas jalur frontostriatal, amigdala, serta hipokampus dan meningkatkan kerentanan untuk depresi. Selain itu sebagian dari faktor herediter juga berperan meningkatkan kerentanan untuk depresi. Keadaan yang bersifat psikososial seperti kemiskinan, isolasi sosial dan lain-lain akan mengundang suatu perubahan psikologis yang selanjutnya akan meningkatkan kerentanan terjadinya depresi pada orang usia lanjut. ${ }^{8}$

Prevalensi depresi pada lanjut usia di dunia berkisar sekitar 8-15\%, dengan perbandingan wanita dengan pria 14,1 : 8,6. Adapun prevalensi depresi pada lanjut usia yang menjalani perawatan di Rumah Sakit dan di Panti perawatan sebesar 30-45\%. Jumlah lanjut usia di Indonesia pada tahun 2005 berjumlah 15.814.511 jiwa atau 7,2\% dan diperkirakan akan bertambah menjadi 11,34\% pada tahun 2020.Pada tahun tersebut depresi akan menduduki peringkat teratas penyakit yang dialami lanjut usia di negara berkembang termasuk Indonesia. ${ }^{9}$

Setiap orang pasti ingin memiliki masa tua yang bahagia tetapi keinginan tidak selalu dapat menjadi nyata. Seorang lanjut usia dalam hidupnya pasti ingin tinggal bersama dengan keluarga terutama anak dan cucu serta mendapatkan perawatan 
yang baik dari keluarganya. Namun karena beberapa faktor, beberapa lanjut usia tidak mendapatkan perawatan dari keluarga, seperti tidak memiliki anak, memiliki anak tetapi anaknya meninggal terlebih dahulu, anak tidak mau direpotkan untuk mengurus orang tua, anak terlalu sibuk dan sebagainya. Karena itulah keluarga memutuskan panti werda sebagai salah satu alternatif untuk mendapatkan perawatan dan pelayanan secara memadai. Keputusan ini tidak seratus persen akan diterima oleh lanjut usia secara lapang dada. Bagi beberapa lanjut usia tinggal di panti werda bukan merupakan pilihan terbaik, bahkan sebaliknya menjadi pilihan pahit yang kadang menyedihkan, Perasaan ini terjadi akibat terputusnya atau hilangnya interaksi sosial yang merupakan salah satu faktor pencetus terjadinya depresi pada lanjut usia yang tinggal di panti werda. ${ }^{10}$

Tujuan dari penelitian ini adalah Mengetahui hubungan lama tinggal dengan tingkat depresi pada lanjut usia yang tinggal di Panti Sosial Tresna Werdha 'Agape' Tondano dan mengetahui gambaran tingkat depresi pada lanjut usia yang tinggal di Panti Sosial Tresna Werdha 'Agape' Tondano

\section{METODE PENELITIAN}

Penelitian ini merupakan analitik observasional dengan desain penelitian cross-sectional yang dilaksanakan pada bulan november sampai desember 2014 di Panti Sosial Tresna Werdha 'Agape' Tondano. Populasi dan sampel diambil sebanyak 50 responden. Teknik pengambilan sampel yaitu memilih sampel dengan kriteria tertentu: lanjut usia yang tinggal di Panti Sosial Tresna Werdha 'Agape' Tondano, berkomunikasi dengan baik, dan bersedia menjadi responden. Pengumpulan data dilakukan dengan menggunakan kuesioner data sosiodemografik dan Hamilton Depression Rate Scale. Data sosiodemografik terdiri dari Nama inisial; umur; jenis kelamin; alamat; agama; status pernikahan; jumlah anak; pendidikan; pekerjaan; alasan masuk; lama tinggal.
Kuesioner HDRS terdiri dari 24 kelompok pernyataan yang menggambarkan 24 kategori sikap dan gejala depresi untuk membantu mengungkapkan tingkat depresi seseorang.Skor berkisar antara 0-4. Pernyataan yang menunjukkan tidak adanya gejala depresi diberi skor 0 , untuk pernyataan yang menggambarkan adanya gejala depresi ringan diberi skor 1 , skor 2 untuk pernyataan yang menggambarkan gejala depresi sedang, skor 3 untuk gejala depresi berat, sedangkan 4 untuk gejala yang sudah sangat berat.

Skor Tingkatan Depresi HDRS.

$<7 \quad$ : Tidak ada depresi

7-17 : Depresi ringan

18-24 : Depresi sedang

$>24$ : Depresi Berat

\section{HASIL PENELITIAN}

Dari total sampel 50 responden lanjut usia yang tinggal di Panti Sosial Tresna Werdha 'Agape' Tondano, responden yang termasuk kategori usia 75-90 tahun, yaitu sebanyak 26 orang (52.0\%). Responden dengan tingkat pendidikan setara SMP, .yaitu sebanyak 26 orang (52.0\%). Responden yang tergolong Tidak Bekerja sebelum masuk panti sebanyak 44 orang (88.0\%).

Responden yang sudah Janda/Duda sebanyak 33 orang (66.0\%). Kemudian responden yang tinggal sudah 7-10 tahun yaitu 23 orang (46.0\%) dan responden dengan alasan masuk dibawa keluarga ke panti, yaitu 29 orang (58.0\%).

Selanjutnya peneliti akan mengklasifikasikan tingkatan depresi menjadi tidak ada depresi, depresi ringan, depresi sedang, dan depresi berat, berdasarkan gejala-gejala depresi yang dirasakan oleh lanjut usia. Berikut adalah hasil penelitian tentang distribusi frekuensi tingkat depresi lanjut usia di Panti Sosial Tresna Werdha ‘Agape’ Tondano. 
Tabel 1. Distribusi Responden Menurut Kategori Umur, Pendidikan, Pekerjaan, Status pernikahan, Lama tinggal, Alasan masuk

\begin{tabular}{lcc}
\hline Karakteristik & Jumlah & \% \\
\hline Umur & & \\
\hline 61-74Tahun & 24 & 48,0 \\
75-90Tahun & 26 & 52,0 \\
>90Tahun & 0 & 0,0 \\
\hline Pendidikan & & \\
\hline Tidak sekolah & 0 & 0,0 \\
SD & 13 & 26,0 \\
SMP & 26 & 52,0 \\
SMA & 8 & 16,0 \\
Perguruan tinggi & 2 & 4,0 \\
Pasca sarjana & 1 & 2,0 \\
\hline Pekerjaan & & \\
\hline Bekerja & 6 & 12,0 \\
Tidak bekerja & 44 & 88,0 \\
\hline Status Pernikahan & & \\
\hline Menikah & 3 & 6,0 \\
Belum menikah & 14 & 28,0 \\
Janda/duda & 33 & 66,0 \\
\hline Lama Tinggal & & \\
\hline 1-3Tahun & 14 & 28,0 \\
4-6Tahun & 13 & 26,0 \\
7-10Tahun & 23 & 46,0 \\
\hline Alasan Masuk & & \\
\hline Kemauan sendiri & 20 & \\
Dibawa sendiri & 29 & \\
Tidak ada keluarga & 1 & \\
\hline
\end{tabular}

Pada Tabel 2 dapat dilihat jumlah lanjut usia terbanyak berada pada tingkat depresi sedang yaitu sebanyak 28 orang (56,0\%), depresi ringan sebanyak 17 orang $(34,0 \%)$, depresi berat sebanyak 3 orang $(6,0 \%)$ dan tidak ada depresi atau kondisi normal sebanyak 2 orang (4,0\%).

Tabel 2. Distribusi Frekuensi Tingkat Depresi Lanjut Usia di Panti Sosial Tresna Werdha Agape’ Tondano.

\begin{tabular}{lcc}
\hline Tingkat depresi & Frekuensi & $\%$ \\
\hline Tidak ada Depresi & 2 & 4,0 \\
Depresi Ringan & 17 & 34,0 \\
Depresi Sedang & 28 & 56,0 \\
Depresi Berat & 3 & 6,0 \\
\hline
\end{tabular}

Hasil tingkatan depresi diperoleh berdasarkan variabel penelitian yang menggambarkan gejala depresi sesuai dengan alat ukur yang digunakan yaitu Hamilton skala pengukuran depresi.

Pada korelasi antara variabel Lama tinggal dengan variabel depresi pada lanjut usia di Panti Sosial Tresna Werdha 'Agape' Tondano didapatkan hasil signifikan, lemah dan tidak searah.

Tabel 3. Grafik hubungan lama tinggal dengan tingkat depresi pada lanjut usia di Panti Sosial Tresna Werdha ‘Agape’ Tondano

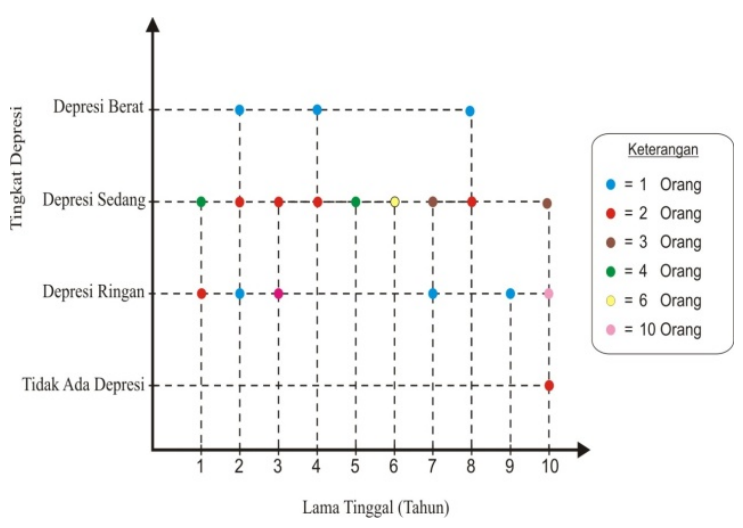

Grafik tersebut menunjukkan bahwa setiap tahunnya masing-masing responden mengalami depresi yang berbeda-beda. Bisa dikatakan bahwa lama tinggal tidak mempengaruhi tingkat depresi pada lanjut usia atau tidak terdapat hubungan antara lama tinggal dengan tingkat depresi pada lanjut usia di Panti Sosial Tresna Werdha 'Agape' Tondano.

\section{BAHASAN}

Berdasarkan hasil penelitian yang telah dilakukan, didapatkan bahwa lanjut usia yang tinggal di Panti Sosial Tresna Werdha 'Agape' Tondano rata-rata berada pada rentang usia 61-90 tahun, dimana jumlah responden terbanyak berada pada usia75-90 tahun yaitu sebanyak 26 orang (52.0\%).

Responden yang berpartisipasi kebanyakan berpendidikan SMP sebanyak 26 orang (52.0\%) dan hanya sebagian kecil responden yang berpendidikan Pasca Sarjana/S2, yaitu 1 orang (2.0\%).

Berdasarkan pekerjaan, jumlah responden yang tidak bekerja khususnya pada kelompok ibu rumah tangga dan 
petani sebanyak 44 orang $(88,0 \%)$ lebih besar dari pada responden yang sebelum masuk panti mempunyai pekerjaan sebanyak 6 orang $(12,0 \%)$.

Pada penelitian ini juga didapatkan responden dengan status pernikahan sebagai Janda/duda lebih banyak dari pada yang masih dalam status menikah. Hasil penelitian ini didapatkan sebanyak 3 orang yang masih dalam status menikah karena di panti ini tinggal sepasang suami-istri yang tidak mempunyai anak dan 1 orang sudah tidak tinggal dengan suaminya tapi belum ada status cerai atau pisah.

Lama tinggal untuk setiap lanjut usia di PSTW Agape Tondano rata-rata berkisar antara 1 hingga 10 tahun. Hasil penelitian responden terbanyak yang sudah lama tinggal di panti ini yaitu responden yang sudah tinggal selama 7-10 tahun sebanyak 23 orang $(46,0 \%)$.

Berdasarkan alasan masuk ke Panti Sosial Tresna Werdha 'Agape' Tondano, didapatkan jumlah responden terbanyak dibawa keluarga yaitu 29 orang $(58,0 \%)$ dari pada responden dengan kemauan sendiri masuk panti. Dalam penelitian ini juga didapatkan 1 orang (2,0\%) lansia yang masuk panti karena tidak punya keluarga.

\section{Prevalensi Tingkat Depresi Pada Lanjut Usia Menurut HDRS (Hamilton Depression Rating Scale)}

Berdasarkan hasil data yang diperoleh dari penelitian yang dilakukan di Panti Sosial Tresna Werdha 'Agape' Tondano, didapatkan sebanyak 96,0\% lanjut usia yang tinggal di Panti Sosial Tresna Werdha 'Agape' Tondano mengalami gangguan depresi, dengan rata-rata berdasarkan skor tingkat depresi sebesar 21 (tingkat sedang). Rata-rata tersebut selaras jika dilihat dari jumlah responden terbanyak yang berada pada tingkatan depresi sedang sebanyak 28 orang (56,0\%), diikuti responden dengan tingkat depresi ringan sebanyak 17 orang (34,0\%). Kemudian responden dengan tingkat depresi berat sebanyak 3 orang (6,0\%) dan responden tidak ada depresi atau kondisi normal sebanyak 2 orang $(4,0 \%)$.

\section{SIMPULAN}

Data hasil penelitian didapatkan sebagian besar lanjut usia yang tinggal di panti werdha berada pada tahap Older yakni pada rentang usia 75-90 tahun Pendidikan terakhir dari responden terbanyak yaitu tingkat pendidikan SMP . Pekerjaan sebelum responden masuk panti terbanyak yaitu yang tergolong tidak bekerja. Status pernikahan dari responden terbanyak yaitu yang termasuk janda/duda. Lama tinggal responden terbanyak yaitu 710 tahun. Alasan masuk responden terbanyak yaitu karena dibawa keluarga.

Tingkat depresi responden terbanyak ialah tingkat depresi sedang sebanyak dan yang paling sedikit alah tidak ada depresi atau kondisi normal.

\section{DAFTAR PUSTAKA}

1. World Health Organization. Depression Disorders Menegament. Updated 2011 November (Di unduh Nov 15, 2011).

URL:http://www.who.int/mental_heal th/management/depression/definition/ en/

2. Maramis W.F. Depresi. Catatan Ilmu Kedokteran Jiwa. Cetakan ketujuh. Surabaya: Airlangga University Press.2004. p, 279-73

3. Amir N, Depresi: Aspek Neurologi, Diagnosis dan Tatalaksana. Jakarta: Fakultas Kedokteran Universitas Indonesia, 2005. p, 1-21

4. Cobelt D. Depresi: Emosi yang Mematikan. Jakarta: Immanuel Publishing House, 2004. p, $17-27$

5. Darmojo RB, Martono HH. Buku Ajar Geriatri. Ed 2. Jakarta: Balai Penerbit FKUI, 2000. p, 1-26

6. Nuryanti T, Indarwati R, Hadisuyatmana

S. Hubungan perubahan peran diri dengan tingkat depresi pada lansia yang tinggal di upt pslu pasuruan barat lamongan. Jurnal unair. Juni 2012

7. Mas'ud, AR. Pembinaan keagamaan lanjut usia. Jurnal multikultural dan multireligius. Maret 2009, vol.8. no. 29

8. Syamsir BS. Gangguan depresi pada orang usia lanjut. Jurnal universitassumatera 
Moniung, Dundu, Munayang: Hubungan lama tinggal...

utara

9. Cahyono AN. Hubungan spiritualitas dengan depresi pada lansia di upt pelayanan sosial lanjut usia magetan. Jurnal Unair. Juni 2012
10. Sari K. Skripsi Gambaran tingkat depresi pada lanjut usia di panti sosial tresna werdha budi mulia 01 dan 03 jakarta timur. Universitas Indonesia. 2012. 